\title{
Galactomannans for Entrapment of Gliomastix murorum Laccase and Their Use in Reactive Blue 2 Decolorization
}

\author{
Itzel C. Romero-Soto ${ }^{1}$, Raúl B. Martínez-Pérez ${ }^{2}$, Jorge A. Rodríguez ${ }^{2}$, Rosa M. Camacho-Ruiz ${ }^{2} \mathbb{D}$, \\ Alejandra Barbachano-Torres ${ }^{2}$, Martha Martín del Campo ${ }^{1}$, Juan Napoles-Armenta ${ }^{3}$ (D), \\ Jorge E. Pliego-Sandoval ${ }^{4}\left(\mathbb{D}\right.$, María O. Concha-Guzmán ${ }^{1, *}$ and María Angeles Camacho-Ruiz ${ }^{1, *(\mathbb{D})}$
}

Citation: Romero-Soto, I.C.;

Martínez-Pérez, R.B.; Rodríguez, J.A.; Camacho-Ruiz, R.M.;

Barbachano-Torres, A.;

Martín del Campo, M.;

Napoles-Armenta, J.;

Pliego-Sandoval, J.E.;

Concha-Guzmán, M.O.;

Angeles Camacho-Ruiz, M.

Galactomannans for Entrapment of

Gliomastix murorum Laccase and Their Use in Reactive Blue 2 Decolorization Sustainability 2021, 13, 9019. https:// doi.org/10.3390/su13169019

Academic Editors: Kuaanan Techato, Mohammad Shah Jamal and Md. Shahariar Chowdhury

Received: 16 June 2021

Accepted: 7 August 2021

Published: 12 August 2021

Publisher's Note: MDPI stays neutral with regard to jurisdictional claims in published maps and institutional affiliations.

Copyright: (c) 2021 by the authors. Licensee MDPI, Basel, Switzerland. This article is an open access article distributed under the terms and conditions of the Creative Commons Attribution (CC BY) license (https:/ / creativecommons.org/licenses/by/ $4.0 /)$.
1 Laboratorio de Investigación en Biotecnología, Centro Universitario del Norte, Universidad de Guadalajara, Colotlán 46200, Jalisco, Mexico; missromero89@hotmail.com (I.C.R.-S.); martha.martindelcampo@academicos.udg.mx (M.M.d.C.)

2 Biotecnología Industrial, Centro de Investigación y Asistencia en Tecnología y Diseño del Estado de Jalisco (CIATEJ), Zapopan 45019, Jalisco, Mexico; rbmperez@gmail.com (R.B.M.-P.); jrodriguez@ciatej.mx (J.A.R.); rcamacho@ciatej.mx (R.M.C.-R.); ale_b_t@hotmail.com (A.B.-T.)

3 Facultad de Agronomía, Universidad Autónoma de Nuevo León, Francisco I. Madero S/N, Ex Hacienda el Cañada, Gral. Escobedo 66050, Nuevo León, Mexico; jnapolesarmenta@gmail.com

4 Laboratorio de Ciencias de la Naturaleza. Centro Universitario del Sur, Av. Enrique Arreola Silva 883, Col Centro, Ciudad Guzmán 49000, Jalisco, Mexico; jorge.pliego@cusur.udg.mx

* Correspondence: mocg@cunorte.udg.mx (M.O.C.-G.); angeles_camacho@cunorte.udg.mx (M.A.C.-R.)

\begin{abstract}
In the present study, a novel laccase from ascomycete Gliomastix murorum was produced in agro-industrial wastes and entrapped in galactomannan beads for Reactive Blue 2 ( $R b-2)$ decolorization. The maximum laccase production in agave bagasse-based medium occurred at $72 \mathrm{~h}$ $\left(1798.6 \mathrm{UL}^{-1}\right)$. Entrapped laccase decolorized $>80 \%$ of $0.5 \mathrm{mM} \mathrm{Rb}-2$ in $2 \mathrm{~h}$ without the addition of redox mediator. $K_{\mathrm{m}}$ for $\mathrm{Rb}-2$ substrate was $1.42 \mathrm{mM}$, with a $\mathrm{V}_{\max }$ of $1.19 \mu \mathrm{mol} \mathrm{min}{ }^{-1}$ for entrapped laccase. Galactomannan matrices produce stability to acid $\mathrm{pH}(2-5)$ tion in the elimination of different dyes, and results showedand temperatures from $20-70{ }^{\circ} \mathrm{C}$. Reusability assays showed that entrapped laccase could retain efficient $\mathrm{Rb}-2$ decolorization of $>80 \%$ six times. In general, galactomannan used for entrapment of laccase provides economic advantages in large-scale wastewater treatment due to its natural origin and efficient results.
\end{abstract}

Keywords: galactomannan beads; ascomycete; laccase; dye decolorization; cibacron blue 3GA; immobilization

\section{Introduction}

Organic synthetic dyes represent one of biggest contamination problems generated by textile, paper, plastics, pharmaceutical, food, and cosmetics industries [1-3]. Dyes are discharged into aquatic environments, damaging ecosystems due to their toxicity. Consequently, there is a reduction in photosynthetic activity by the obstruction of solar rays. In addition, dyes represent a risk to human health due to their potential mutagenic and carcinogenic effects [4]. Reactive anthraquinoic dyes have a stable aromatic structure, which makes their elimination difficult. These dyes represent around 20-30\% of dyes used worldwide [5]. They have a low fixation in cotton, wool garments, and others during the dyeing stage, which means around $8-35 \%$ of dyes applied are discharged into residual effluents [6,7].

Reactive Blue $2(\mathrm{Rb}-2)$ is an anthraquinoic dye, its structure is a triazine with amino and sulfate groups, giving it high stability and resistance to degradation by biological systems and chemical treatments $[8,9]$. Due to this problem, several efforts have been made to remove $\mathrm{Rb}-2$ from the environment. Traditionally, different physical treatments have been proposed to eliminate this pollutant, such as filtration, sedimentation, and adsorption, which generate fewer toxic by-products. However, these techniques do not 
achieve mineralization of the pollutant [1]. In addition, advanced oxidation systems such as electrooxidation, electrocoagulation, chemical coagulation, photodegradation, and coupled systems have also been evaluated (biologically advanced systems) [10-12]. Wastewater treatment requires high energy loads and also chemical compounds, which represent an increase in toxicity of treated effluents [13].

Some strategies with biological treatments, mainly anaerobic systems, have been incorporated into the degradation of reactive anthraquinoic dyes, with elimination reaching $90 \%$ with residence times ranging from 8-24 h [14]. The use of these systems for colorant elimination is an economically and environmentally sustainable option. However, only a proportion of pollutants are adsorbed onto the granules' surfaces (the same happens with physical processes), and the absorbed colorant fails to mineralize completely, generating highly toxic degradation by-products [15]. Likewise, biological systems with selective bacteria [2], fungi [16,17], and enzymes [18] have been incorporated to eliminate these pollutants.

In the degradation of reactive anthraquinoic dye using catalysts, enzymes are responsible for hydrolyzing and oxidizing contaminants. The use of specific enzymes for pollutant degradation reduces operating times and costs, and allows optimization of the treatment. Laccases are enzymes commonly called blue multicopper oxidases, and they are the most widely distributed of all the large blue copper-containing proteins [19]. They are produced by a wide variety of microorganisms such as bacteria [20], yeast [21], and fungi [22] isolated from different environments [23]. Basidiomycete and bacterial laccases have been widely reported; however, using these enzymes for dye removal requires the use of redox mediators $[19,24]$ Mtibaa et al. [20] reported ascomycete laccases that do not require the incorporation of this type of mediator. Refs [25-27] Data of laccase production from the genus Gliomastix is limited. In Mexico, there are many environments in which to obtain microorganisms capable of producing these kinds of enzyme [21,22].

The challenge in catalyst application in residual effluent treatment is the immobilization and/or trapping of enzymes in a system that facilitates recovery for reuse. Different hydrogels for enzyme immobilization have been used, such as: poly hydroxyethyl methacrylate-co-vinylene carbonate p (HEMMA-co-VC), chitosan [28], genipin-activated chitosan [24], polyacrylamide-alginate cryogel [29], Ca-alginate [25], and others. Galactomannans are polysaccharides used as thickeners and emulsifiers in the food industry, their main advantage is that they are obtained from the endosperm seeds of numerous plants, mainly legumes $[26,27]$, which means that it is an economical option for enzymatic trapping. For this reason, the main objective of this work was to evaluate the degradation of Rb-2 in synthetic water using ascomycete laccase Gliomastix murorum sp. HP3 trapped in galactomannan beads.

\section{Materials and Methods}

\subsection{Materials}

Galactomannan polysaccharide (M.W. of approx. $310 \mathrm{kDa}$ ) from Ceratonia siliqua (algarrobo) seeds, lignin alkali and Reactive Blue 2 (Cibacron Blue 3GA) were purchased from Sigma-Aldrich ${ }^{\circledR}$ (Merck KGaA, Darmstadt, Germany). Agave bagasse, which is an agro-industrial waste derived from agave distillates, was supplied by a local distiller company; before use, it was ground and sieved to a particle size less than $0.149 \mathrm{~mm}$.

\subsection{Isolation, Screening, and Identification of Laccase-Producing Microorganism}

Isolations were made from soil samples from Tamuín, San Luis Potosí, Mexico. Sample suspensions in sterile distilled water with $1 \%$ Tween 80 were diluted in a ratio of $10 \mathrm{~mL}$ of water for each gram of soil. They were incubated for $1 \mathrm{~h}$ at room temperature $\left(25^{\circ} \mathrm{C}\right)$ and agitation $(250 \mathrm{rpm})$. Decimal dilutions were made from $10^{-1}$ to $10,000^{-1}$ in sterile $150 \mathrm{mM} \mathrm{NaCl}$, and $100 \mu \mathrm{L}$ in Petri dishes of $10 \mathrm{~cm}$ diameter were inoculated with Küster medium [30], formulated with ( $\mathrm{g} \mathrm{L}^{-1}$ ): glycerol, 10; casein, 0.3; $\mathrm{KNO}_{3}, 2 ; \mathrm{NaCl}, 2$; $\mathrm{K}_{2} \mathrm{HPO}_{4}, 2 ; \mathrm{MgSO}_{4} \cdot 7 \mathrm{H}_{2} \mathrm{O}, 0.05 ; \mathrm{CaCO}_{3}, 0.02 ; \mathrm{FeSO}_{4} \cdot 7 \mathrm{H}_{2} \mathrm{O}, 0.01$, and bacteriological agar, 
18. Isolated colonies were collected and passed on a fresh agar medium, then biomass was recovered and stored in $20 \%$ glycerol at $-20{ }^{\circ} \mathrm{C}$.

Screening of laccase-producing strains was performed in agar plates using $1 \%$ lignin as the sole carbon source to replace soluble starch in Küster medium. The appearance of a brown halo around the colony was considered positive for laccase production.

The selected strain was identified by molecular analysis. A fresh microorganism culture was used to DNA extraction with a commercially available kit, Dneasy ${ }^{\circledR}$ Plant Mini Kit (Qiagen, Hilden, Germany). The PCR was made using OneTaq ${ }^{\circledR}$ DNA polymerase (New England Biolabs, Ipswich, MA, USA) on a 96-well thermal cycler (Veriti ${ }^{\mathrm{TM}}$, Applied Biosystems, Foster City, CA, USA). The primers ITS1 and ITS4 [31] were employed to amplify approximately $600 \mathrm{bp}$ fragments from the transcribed spacer region in the nuclear ribosomal repeat unit. The PCR product was sequenced by Macrogen USA Corp. (Rockville, MD, USA). Consensus sequences were analyzed using the CLC Main Workbench 5.5 software (CLCBio, Aarhus, Denmark). The BLAST algorithm was used to compare obtained sequences with the nucleotide GenBank database [32]. A phylogenetic tree was built where the evolutionary distances were computed using the Maximum Composite Likelihood method [33].

\subsection{Culture Conditions}

The culture medium was optimized for laccase production as described in Supplementary Data. The effect of nitrogen, carbon, and co-substrate was studied by multivariate and surface response experimental designs. The optimized medium contained $\left(\mathrm{g} \mathrm{L}^{-1}\right)$ : glucose, 12.0; agave bagasse, 28.0; urea, 2.6; $\mathrm{NaCl}, 2.0 ; \mathrm{K}_{2} \mathrm{HPO}_{4}, 2.0 ; \mathrm{MgSO}_{4} \cdot 7 \mathrm{H}_{2} \mathrm{O}, 0.05 ; \mathrm{CaCO}_{3}, 0.02$; $\mathrm{FeSO}_{4} \cdot 7 \mathrm{H}_{2} \mathrm{O}, 0.01$, and was inoculated with $5 \times 10^{5}$ spores $\mathrm{m} \mathrm{L}^{-1}$ of a fresh surface culture and incubated at $30{ }^{\circ} \mathrm{C}$ in Erlenmeyer flasks with orbital shaking at $250 \mathrm{rpm}$. Laccase activity was monitored for $120 \mathrm{~h}$. The biomass generation was estimated by weight difference. The reducing sugars quantification was performed using Miller's DNS method [34]. A standard glucose curve was used as a reference.

\subsection{Enzyme Extraction}

The culture of Gliomastix murorum was stopped at $72 \mathrm{~h}$ to obtain the maximum production of laccase activity. The extracellular extract was recovered by centrifugation at $10,000 \mathrm{rpm}$ for $10 \mathrm{~min}$ at $4^{\circ} \mathrm{C}$ and frozen at $-20^{\circ} \mathrm{C}$ until its subsequent use.

\subsection{Activity Assays}

Laccase activity was determined by monitoring the oxidation of $7.5 \mathrm{mM}$ ABTS (2,2' azino bis (3 ethylbenzthiazoline-6-sulfonic acid)) in $100 \mathrm{mM}$ citrate-phosphate buffer, $\mathrm{pH} 6$ at $\lambda_{\max }=405 \mathrm{~nm}$. Assays were carried out in a 96-well plate in $200 \mu \mathrm{L}$ (estimated $0.6 \mathrm{~cm}$ path length) of reaction volume, which was incubated at $37^{\circ} \mathrm{C}$ and monitored every $30 \mathrm{~s}$ in a microplate spectrophotometer $\left(\mathrm{Epoch}^{\mathrm{TM}} 2, \mathrm{BioTek}^{\mathrm{TM}}\right)$. One unit of enzymatic activity corresponds to $1.0 \mu \mathrm{mol}$ of ABTS oxidized per minute under test conditions. An ABTS molar extinction coefficient of $36.8 \mathrm{mM}^{-1} \mathrm{~cm}^{-1}$ was used [35].

Reactive Blue $2(\mathrm{Rb}-2)$ was evaluated as a substrate for laccase. Enzyme activity was tested under the same $\mathrm{pH}(6)$, temperature $\left(37^{\circ} \mathrm{C}\right)$, and stirring conditions as per ABTS. In contrast to this, the $\mathrm{Rb}-2$ assay was monitored at $\lambda_{\max }=610 \mathrm{~nm}$. One unit of enzymatic activity corresponds to $1.0 \mu \mathrm{mol}$ of $\mathrm{Rb}-2$ degraded per minute under test conditions. The molar extinction coefficient came from a standard curve $\left(8.4 \mathrm{mM}^{-1} \mathrm{~cm}^{-1}\right)$.

\subsection{Preparation of Galactomannan/Laccase Beads}

Galactomannan $\left(1.8 \mathrm{~g} \mathrm{~L}^{-1}\right)$ was dissolved in distilled water. Laccase extract (50:50) $v / v$ was prepared. First, galactomannan solution was heated in a $1500 \mathrm{~W}$ microwave oven on high power for $15 \mathrm{~s}$; then when the mix was cold $\left(25^{\circ} \mathrm{C}\right)$, the laccase extract was added. The mixture was stirred using a magnetic stirrer to ensure complete mixing. For bead preparation, the mixture was added dropwise to a beaker containing $100 \mathrm{~mL}$ of acetone 
at $4{ }^{\circ} \mathrm{C}$, and it was left under constant orbital shaking at $50 \mathrm{rpm}$ for $1 \mathrm{~h}$. The beads were recovered using a strainer and placed on a glass plate for $10 \mathrm{~min}$ at $25^{\circ} \mathrm{C}$ to ensure complete evaporation of the acetone. The enzymatic activity (EA) was measured in the beads that were obtained. The beads were stored at $4{ }^{\circ} \mathrm{C}$ for later use. A schematic illustration of bead preparation is shown in Figure 1.

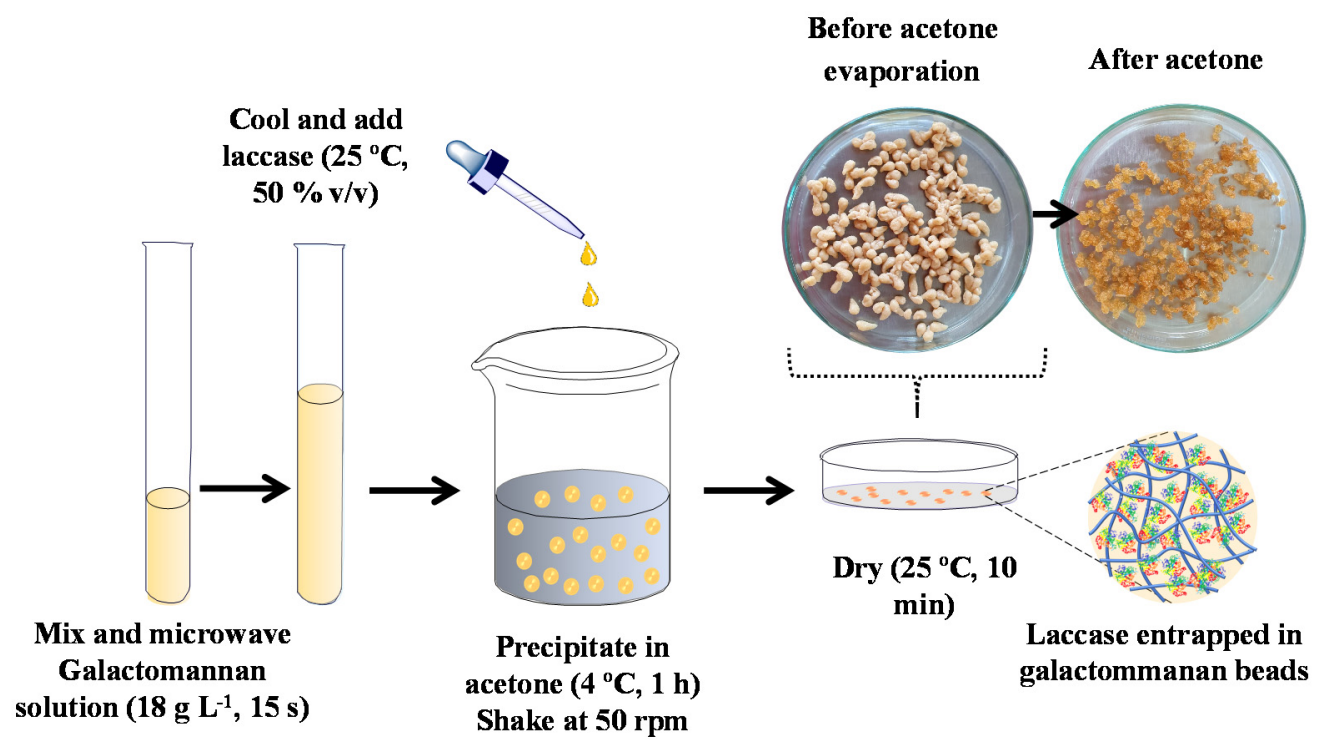

Figure 1. Schematic illustration of galactomannan/laccase bead preparation.

\subsection{Reactive Blue 2 Decolorization Assays}

The $\mathrm{Rb}-2$ decolorization by galactomannan entrapped laccase was conducted in conical tubes containing $5.0 \mathrm{~mL}$ of $0.5 \mathrm{mM} \mathrm{Rb}-2$ (dissolved in $100 \mathrm{mM}$ citrate-phosphate, $\mathrm{pH} \mathrm{6)}$ and 3 beads of entrapped laccase $\left(0.39 \mathrm{mU} \mathrm{mg}^{-1}\right.$ of catalyst). A simultaneous experiment with equal activity units of free laccase and the same reaction conditions was performed. Samples were incubated on an orbital shaker at $250 \mathrm{rpm}$ and $37^{\circ} \mathrm{C}$. A sample $(200 \mu \mathrm{L})$ was taken every $20 \mathrm{~min}$ and analyzed spectrophotometrically at $\lambda_{\max }=610 \mathrm{~nm}$. The extent of decolorization was expressed in terms of a percentage calculated as follows:

$$
\text { Decolorization }(\%)=\frac{\left(\mathrm{A}_{0}-\mathrm{A}_{\mathrm{t}}\right)}{\mathrm{A}_{0}} \times 100
$$

where $A_{0}$ is the initial absorbance and $A_{t}$ is the absorbance of test sample. All samples were analyzed in triplicate.

To determine the possible adsorption of $\mathrm{Rb}-2$ on galactomannan beads, control experiments with galactomannan enzyme free beads where also conducted.

\subsection{Effect of Temperature and $p H$ on the Enzyme Stability}

Thermostability tests of the free and entrapped laccases were carried out by incubating the enzyme at different temperatures, ranging from $4{ }^{\circ} \mathrm{C}$ to $80^{\circ} \mathrm{C}$, using $100 \mathrm{mM}$ citratephosphate ( $\mathrm{pH}$ 6). Furthermore, the stability at different $\mathrm{pH}$ was analyzed, incubating the enzyme preparations in different $100 \mathrm{mM}$ citrate-phosphate buffer solutions (pH 2-9) at room temperature.

In both studies, the sample was left under assay conditions for $120 \mathrm{~min}$; next, the residual activity was measured using ABTS as the substrate for the reaction at $\mathrm{pH} 6$. Assays were carried out in triplicate on $2 \mathrm{~mL}$ microtubes containing $0.5 \mathrm{~mL}$ of buffer. Residual activity was calculated considering the maximum activity as $100 \%$. For activity tests, the entrapped laccase was recovered by draining the beads, while the free enzyme was conveniently diluted in $100 \mathrm{mM}$ citrate-phosphate buffer at pH 6 . 


\subsection{Reusability Capacity of Entrapped Laccase}

The reusability test was evaluated in batch. A bead of entrapped laccase with an initial activity of $0.39 \mathrm{mU} \mathrm{mg}^{-1}$ of catalyst and $0.5 \mathrm{~mL}$ of $0.5 \mathrm{mM} \mathrm{Rb}-2$ (dissolved in $100 \mathrm{mM}$ citrate-phosphate, $\mathrm{pH}$ 6) were placed in $2 \mathrm{~mL}$ microtubes. Tubes were incubated on an orbital shaker $(250 \mathrm{rpm})$ at $37^{\circ} \mathrm{C}$ for $30 \mathrm{~min}$. Samples were taken at the beginning and after the incubation time to determine the decolorization (\%). After one cycle of decolorization, the liquid was withdrawn, and $0.5 \mathrm{~mL}$ of fresh $\mathrm{Rb}-2$ solution was added to initiate a new cycle. A total of 7-batch cycles were evaluated. Decolorization was reported as the percentage of dye elimination in every batch test. Dye decolorization in the first cycle was considered as $100 \%$.

\section{Results and Discussion}

\subsection{Isolation, Screening, and Identification of Laccase-Producing Microorganism}

A total of 33 strains were isolated from soil samples from El Tamuín, San Luis Potosí, Mexico. These were screened in a selective medium containing lignin as the sole carbon source. After 14 days, 4 strains had grown, and only the strain HP3 generated a brown halo around the colony, indicating laccase production (Figure S2).

The PCR amplification of the ITS region (476 bp) of HP3 and phylogenetic analysis (Figure 2) revealed that the most closely related fungal strain was Gliomastix murorum sp. JCKQF8 (sequence ID: KT968540.1), with 99.58\% identity. Ten sequences were selected to make the phylogenetic tree based on, the identity percentage, the score, and the query cover.

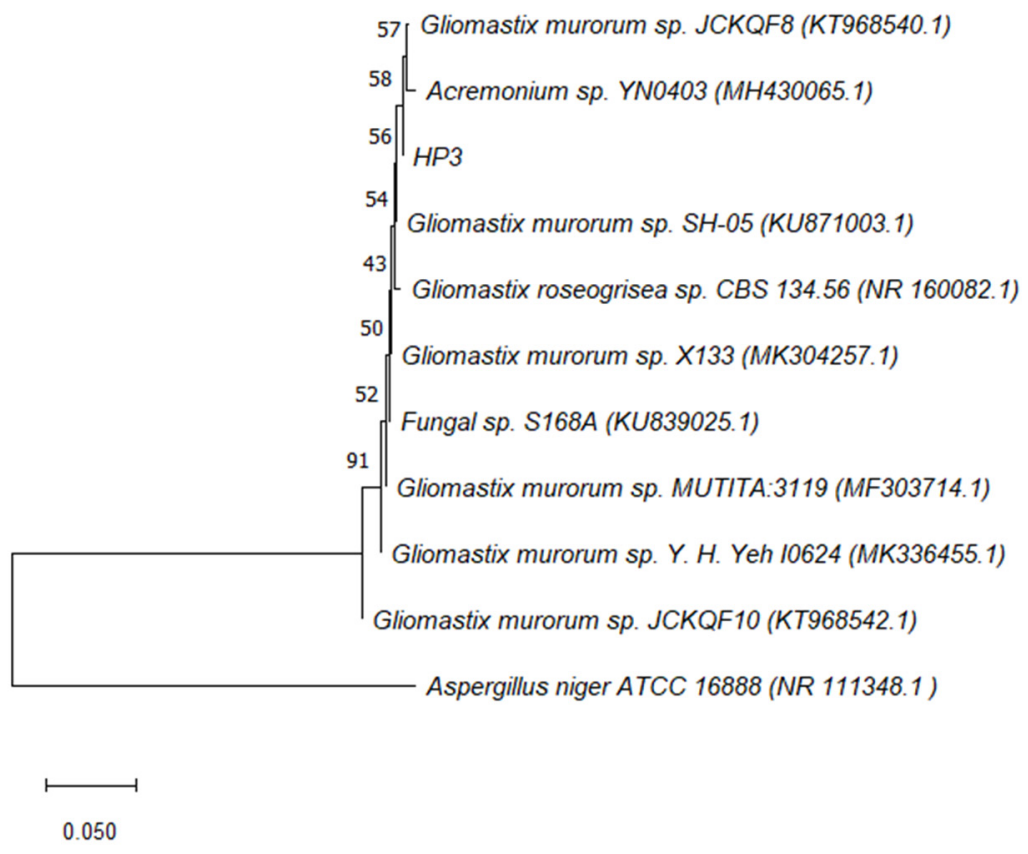

Figure 2. Phylogenetic tree based on ITS rRNA gene sequence showing the position of strain HP3 and Gliomastix murorum related species. Aspergillus niger was used as an out-group. Numbers at the nodes are bootstrap values (of 1000 replicates).

G. murorum is a type of saprophyte belonging to the order Hypocreales, which are related to the Dothideales, Magnaporthales, Capnodiales, and Leotiomycetes as ascomycetous fungi responsible for the degradation of lignocellulosic materials in forest litter and soil [36]. To our knowledge, no laccase activity has been reported in this genus; furthermore, there are few ascomycete laccases reported in the literature, and most of the laccases that have been studied in depth come from the division Basidiomycetes [18]. 


\subsection{Laccase Production}

Gliomastix murorum sp. HP3 was grown in agave bagasse-based medium to produce laccase. The same profile was observed between enzyme production and cell biomass, the maximum enzyme activity was reached at $72 \mathrm{~h}$ of culture (1798.6 $\mathrm{U} \mathrm{L}^{-1}$ ) (Figure 3). This phenomenon was similar to laccases produced by white-rot fungi grown in natural substrates, such as agricultural residues in submerged fermentation [37,38]. However, Myasoedova et al. [39] observed that the maximum production of laccase activity in Hypocreal ascomycetes occurs between three and seven days when they are grown in a mineral medium with a complex carbon source (grain crops or potato).

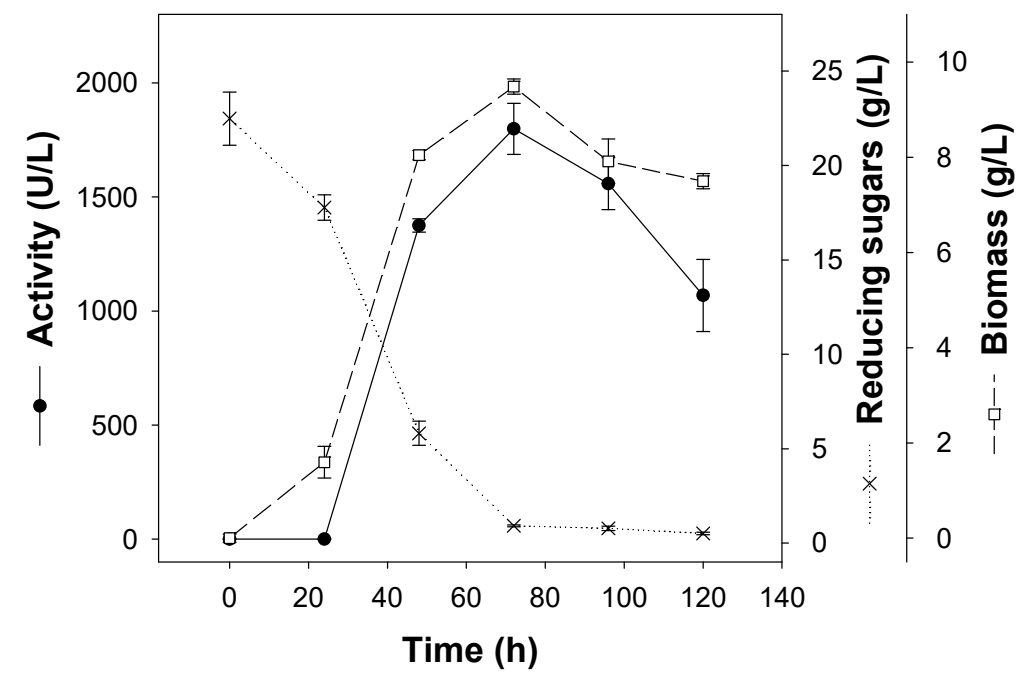

Figure 3. Growth kinetics of Gliomastix murorum sp. HP3 and its production of extracellular laccases in a culture medium based on agave bagasse.

On the other hand, it can be observed that both the production of laccase and the growth of the strain decline at the time the reducing sugars are exhausted; this can be solved through a fed batch fermentative strategy, which takes into account both the catabolic repression by glucose, as well as the maintenance of the culture [40].

\subsection{Kinetic Parameters of Free and Entrapped Laccase}

The kinetic parameters of the free and immobilized enzyme were determined for the oxidation of 2,2' azino bis (3 ethylbenzthiazoline-6-sulfonic acid) (ABTS) and Reactive Blue $2(\mathrm{Rb}-2)$ decolorization. Kinetics were performed using a range of substrate concentrations, and the results obtained are shown in Table 1. Both free and entrapped laccase showed a higher affinity for $\mathrm{Rb}-2$ than for ABTS, while $\mathrm{V}_{\max }$ was higher in the oxidation of ABTS for entrapped enzyme. The results suggest that the immobilization of laccases in galactomannan beads does not modify the nature of the enzyme; however, the lower catalytic rate can be attributed to diffusion phenomena within the hydrogel, causing low accessibility of the substrate to the active sites [24]. Gliomastix murorum sp. HP3-free laccase presented greater affinity for ATBS than entrapped laccase; similar results were found for Thielavia sp. ascomycete and Trametes pubescens laccase-free $[20,24,41]$. Nevertheless, $V_{\max }$ for ABTS substrate in entrapped laccase was 2.5 times higher than free laccase, and the opposite was true for $\mathrm{Rb}-2$ substrate; $\mathrm{V}_{\max }$ of 5.67 for free laccase and 1.19 for entrapped laccase, respectively. 
Table 1. Kinetic parameters of free and entrapped laccases.

\begin{tabular}{|c|c|c|c|}
\hline Enzyme & Substrate & $V \max \left(\mu \operatorname{mol} \min ^{-1}\right) *$ & $\mathrm{Km}(\mathrm{mM})$ \\
\hline \multicolumn{4}{|l|}{ Free } \\
\hline & ABTS & 3.05 & 0.28 \\
\hline & $\mathrm{Rb}-2$ & 5.67 & 0.18 \\
\hline \multicolumn{4}{|l|}{ Entrapped } \\
\hline & ABTS & 7.54 & 6.00 \\
\hline & $\mathrm{Rb}-2$ & 1.19 & 1.42 \\
\hline
\end{tabular}

* Rate per gram (entrapped) or milliliter (free) of sample.

\subsection{Evaluation of Laccase in Reactive Blue 2 Decolorization}

The effectiveness of free and entrapped laccase in Rb-2 decolorization is shown in Figure 4 . $\mathrm{Rb}-2$ was $82 \%$ decolorized after $2 \mathrm{~h}$ of treatment with entrapped laccase; as expected, the treatment with the free enzyme reached $100 \%$ at the same time.

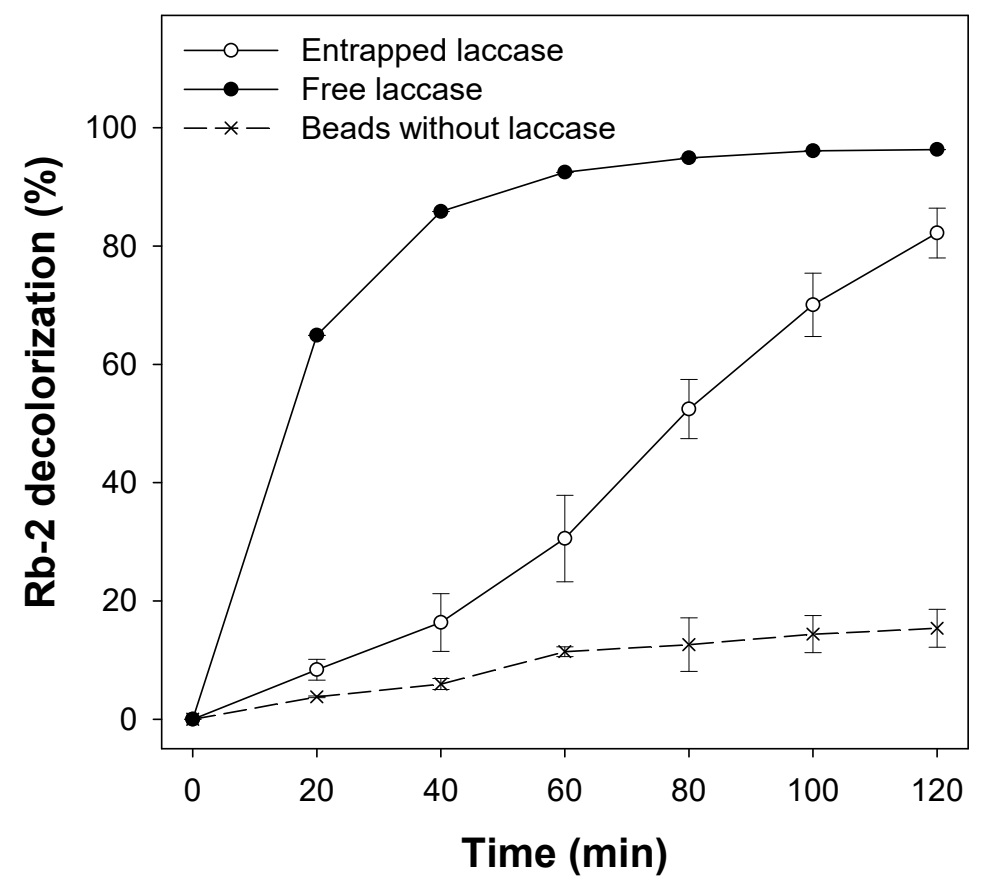

Figure 4. Decolorization of Reactive Blue $2(0.5 \mathrm{mM})$ by free and entrapped laccase. The kinetics were performed with $0.39 \mathrm{mU} \mathrm{mg}^{-1}$ of laccase at $37^{\circ} \mathrm{C}, \mathrm{pH} 6.0$, under orbital shaking $(250 \mathrm{rpm})$. The change in absorbance at $610 \mathrm{~nm}$ was used to compute the percent decolorization. Galactomannan beads without enzyme was used as control.

The use of galactomannan for enzyme entrapment has not been reported before. Different hydrogels for enzyme immobilization have been used. Bayramoglu et al. [15] immobilized laccase (Trametes versicolor) in poly hydroxyethyl methacrylate-co-vinylene carbonate $\mathrm{p}$ (HEMMA-co-VC) microbeads with acetosyringone as mediator, finding $43 \%$ Cibacron Blue 3GA degradation in a $2 \mathrm{~h}$ contact period. Ma et al. [24] found $77.49 \%$ removal of the dye Acid Black 172 through laccase (Trametes pubescens) immobilized by genipinactivated chitosan beads after $96 \mathrm{~h}$ of incubation. Zheng et al. [28] studied Acid Black 172 dye, finding $68.84 \%$ decolorization efficiency after a $48 \mathrm{~h}$ reaction by laccase (Trametes pubescens) immobilized in chitosan beads using glutaraldehyde as crosslinker; both studies used $50 \mathrm{mg} \mathrm{L}^{-1}$ as the initial dye concentration. Likewise, polyacrylamide-alginate cryogel was used for laccase (Trametes versicolor) immobilization in the elimination of different dyes,

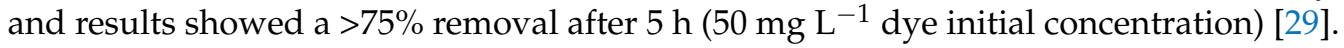


On the other hand, synthetic mediators are usually applied to improve dye oxidation; however, they are toxic compounds and their application increases dye treatment costs [19]. Gliomatix murorum sp. HP3 laccase does not require the addition of mediators to obtain high dye decolorization. In this work, more than $60 \%$ decolorization of $\mathrm{Rb}-2$ ( $0.5 \mathrm{mM}$ initial concentration) was achieved in the first 20 min when free laccase was used, while Othman et al. [42] observed a $29.29 \%$ decolorization of Rb-2 ( $0.12 \mathrm{mM}$ initial concentration) after 35 min reaction using a laccase extract of the Basidiomycete Agaricus bisporus CU13, adding HBT $1 \mathrm{mM}$ as mediator.

These results highlight the potential applications that laccase derived from Gliomatix murorum sp. HP3 entrapped in galactomannan beads has for dye removal over other hydrogel matrices, with the additional benefit of not requiring the addition of mediators.

\subsection{Temperature and $p H$ Effects on the Stability of Free and Entrapped Laccase}

The effect of temperature $\left(4-80^{\circ} \mathrm{C}\right)$ on free and entrapped laccases was evaluated (Figure 5a). The temperature effect on laccase stability was different from the free and entrapped enzyme. For free laccase, residual activity decreased near $55 \%$ after $20{ }^{\circ} \mathrm{C}$ and kept decreasing as the temperature increased, while for entrapped laccase, residual activity remained $>95 \%$ until $40{ }^{\circ} \mathrm{C}$ and decreased $<50 \%$ after $50{ }^{\circ} \mathrm{C}$. These results show an increase in the thermal stability of the enzyme when galactoatches of $30 \mathrm{~min}$ were analyzed. Residual activimannan is used. Biopolymer use confers additional resistance and a protective microenvironment matrix.

\section{a)}

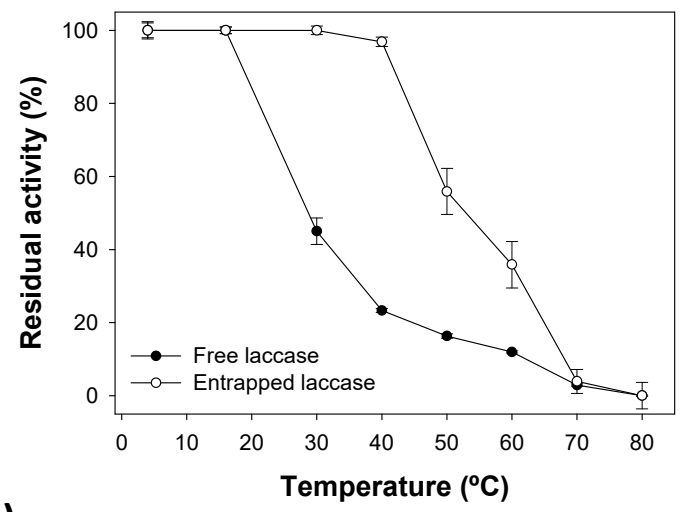

b)

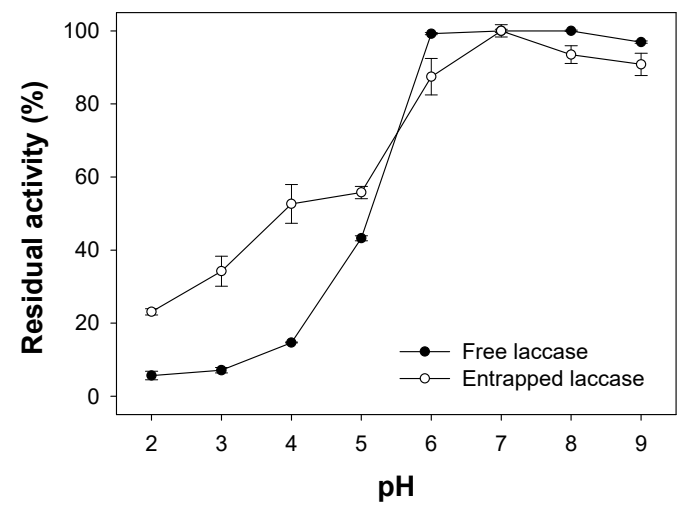

Figure 5. Effect of temperature (a) and $\mathrm{pH}(\mathbf{b})$ on stability of free and entrapped laccase. Enzymes were pre-incubated for $2 \mathrm{~h}$ under test conditions; after that, their residual activity was measured at $\mathrm{pH} 6$ in $\mathrm{Rb}-2$ as substrate and then calculated based on the activity of non-incubated enzyme as control $(100 \%)$.

The effect of $\mathrm{pH}(2-9)$ on stability of free and entrapped laccases was evaluated (Figure 5b). Entrapped laccase presented higher residual activity $(23.75 \pm 11.25)$ to acidic 
$\mathrm{pH}(2-5)$. Similar residual activity was maintained for free and entrapped laccase to alkaline $\mathrm{pH}(6-9)$. Lassouane et al. [41] found high stability under acidic conditions (pH 3-6) in crosslinked-entrapped laccase in Ca-alginate beads, and more than $80 \%$ of its initial activity was retained. Results suggest that galactomannan hydrogel protects enzyme against acidic $\mathrm{pH}$.

\subsection{Reusability of Entrapped Laccase}

The capacity of reusability of immobilized laccase is one of the most important indicators in industrial enzymatic applications (for reducing the cost) [41]. Therefore, it is necessary to investigate the feasibility of reusing the biocatalyst immobilized on different substrates [28,43]. Laccases entrapped in galactomannan beads have not been studied before. In this work, seven successive batches of $30 \mathrm{~min}$ were analyzed. Residual activity was $>90 \%$ after four cycles and $>80 \%$ after six cycles (Figure 6). It is worth noting that, at $30 \mathrm{~min}$ of reaction, $20 \%$ decolorization was achieved and, to reach an $80 \%$ level, $120 \mathrm{~min}$ are needed; the difference in operation time could affect the loss of activity, lowering the reusability.

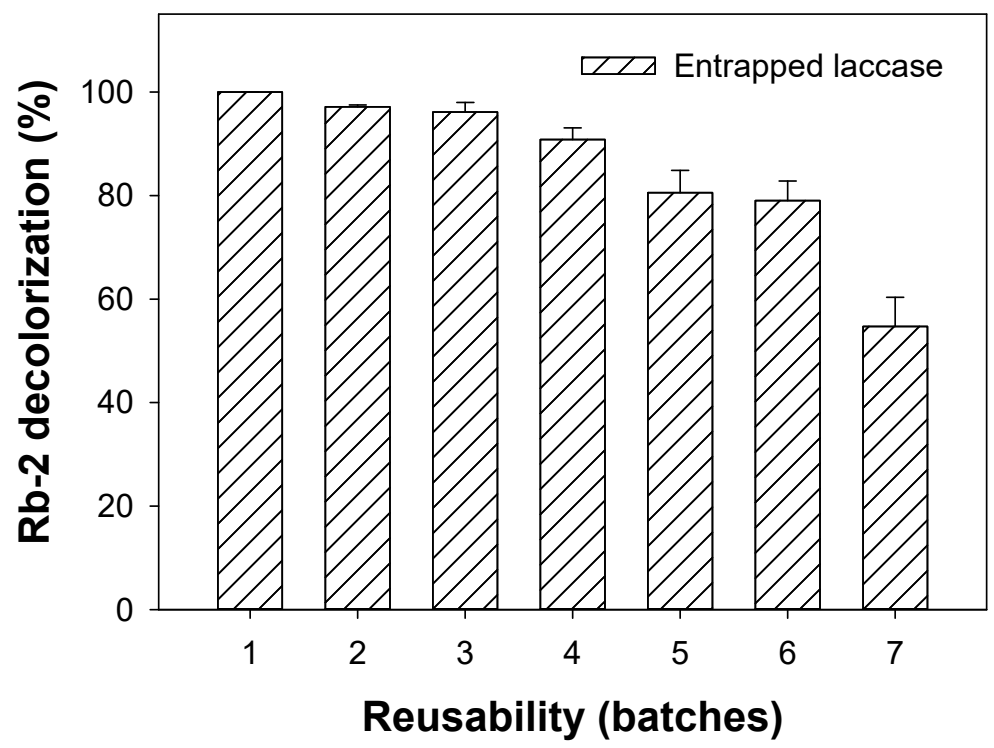

Figure 6. Effect of reuse on the activity of entrapped laccase. The assays were performed with $0.39 \mathrm{mU} \mathrm{mg}{ }^{-1}$ of laccase at $37^{\circ} \mathrm{C}, \mathrm{pH} 6$, under orbital shaking $(250 \mathrm{rpm})$. After one cycle of decolorization, the liquid was withdrawn, and a fresh $\mathrm{Rb}-2$ solution $(0.5 \mathrm{mM}, \mathrm{pH}$ 6) was added to initiate a new cycle.

Results obtained from the reuse test of laccase entrapped in galactomannans are similar to those reported by Zheng et al. [28], who used chitosan to immobilize the laccase of Trametes pubescens, with a residual activity $>60 \%$ after six cycles. Alginate is another widely used hydrogel for the entrapment of enzymes in the removal of dyes and other compounds. Reda et al. [43] found that the relative activity of the enzyme immobilized in alginate retains approximately $65 \%$ of activity after the seventh cycle. Daàssi et al. [25] detected that, after the fourth cycle, the discoloration values were $>70 \%$ in laccase immobilized in Ca-alginate beads. It is worth mentioning that combinations of different matrices have been made to increase the reuse of immobilized enzymes. Some studies report the combination of graphene oxide in alginate to degrade different compounds, finding decolorizations $>75 \%$, with reuse between four and six cycles $[36,44]$. The decrease in enzyme activity could be attributed to the inactivation and loss of enzyme molecules during each cycle [28]. Furthermore, the environment of the solution could induce some conformational changes in the enzyme during continuous reprocessing, which would cause a decrease in the performance of catalytic activity [45]. 
The results suggest that the use of galactomannans for laccase entrapment implies excellent operational stability and good reusability.

\title{
4. Conclusions
}

The laccase produced by ascomycetes Gliomastix murorum sp. HP3 exhibits a greater affinity for Reactive Blue $2(\mathrm{Rb}-2)$ decolorization, an anthraquinoid dye of significant toxicity, than by 2,2' azino bis ( 3 ethylbenzthiazoline-6-sulfonic acid) (ABTS), which is the conventional substrate for laccases. In addition, the catalytic rate is similar to that reported for other laccases that require the addition of redox mediators. The galactomannans matrix generated for the entrapment of laccases conferred enzyme stability against temperature and $\mathrm{pH}$. The use of biopolymer allowed the enzyme to be reused for up six cycles, maintaining $82 \%$ in $\mathrm{Rb}-2$ decolorization activity. Using hydrogels based on galactomannans for enzymatic trapping is a viable alternative which offers the advantage of obtaining dye beads that could be stored under ambient conditions.

Supplementary Materials: The following are available online at https:/ /www.mdpi.com/article/ 10.3390/su13169019/s1, Figure S1: Pareto analysis plot of effect of A inductor, B substrate and C nitrogen, on yield of enzyme production, Figure S2: Main effects plot: inductor (agave and cane), substrate (glucose and starch) and nitrogen (potassium nitrate and urea) for enzyme production yield, Figure S3: Interaction plot: Inductor and substrate (upper left), inductor and nitrogen (lower left) and substrate and nitrogen (lower right) on enzyme production yield, Figure S4: Response surface showing the interaction between three parameters and extracellular laccase production, Table S1: Experimental multifactorial design for screening of medium components for Gliomastix murorum (strain HP3) laccase production, Table S2: Response surface design.

Author Contributions: Conceptualization, R.B.M.-P., J.N.-A., J.A.R., M.M.d.C., M.A.C.-R. and I.C.R.S.; methodology, R.B.M.-P., R.M.C.-R., A.B.-T., J.E.P.-S., M.O.C.-G. and I.C.R.-S.; software, M.A.C.-R., M.O.C.-G. and I.C.R.-S.; validation, R.B.M.-P., M.A.C.-R. and I.C.R.-S.; formal analysis, M.A.C.-R., R.B.M.-P., M.O.C.-G. and J.A.R.; investigation, M.A.C.-R., M.O.C.-G. and I.C.R.-S.; resources, J.A.R., R.M.C.-R., A.B.-T., M.M.d.C., M.O.C.-G. and M.A.C.-R.; data curation, J.N.-A., J.E.P.-S., R.B.M.-P., M.A.C.-R., A.B.-T. and I.C.R.-S.; writing-original draft preparation, R.B.M.-P., M.O.C.-G., M.A.C.-R. and I.C.R.-S.; writing-review and editing, R.B.M.-P., M.O.C.-G., M.A.C.-R. and I.C.R.-S.; visualization, J.N.-A., J.A.R. and R.M.C.-R. All authors have read and agreed to the published version of the manuscript.

Funding: This project was financed by the Sectorial Research and Education Fund SEP/CONACyT, Mexico (CB-2016/283183).

Institutional Review Board Statement: Not applicable.

Informed Consent Statement: Not applicable.

Data Availability Statement: Not applicable.

Acknowledgments: I.C.R.-S. acknowledges the SEP/CONACyT for her postdoctoral fellowship.

Conflicts of Interest: The authors declare no conflict of interest.

\author{
Abbreviations \\ The following abbreviations are used in this manuscript: \\ ABTS 2,2' azino bis (3 ethylbenzthiazoline-6-sulfonic acid) \\ BLAST Basic Local Alignment Search Tool \\ DNS dinitrosalisylic acid \\ Rb-2 Reactive Blue 2
}

\section{References}

1. Ranjbar, D.; Raeiszadeh, M.; Lewis, L.; MacLachlan, M.J.; Hatzikiriakos, S.G. Adsorptive removal of Congo red by surfactant modified cellulose nanocrystals: A kinetic, equilibrium, and mechanistic investigation. Cellulose 2020, 27, 3211-3232. [CrossRef]

2. Britos, C.N.; Gianolini, J.E.; Portillo, H.; Trelles, J.A. Biodegradation of industrial dyes by a solvent, metal and surfactant-stable extracellular bacterial laccase. Biocatal. Agric. Biotechnol. 2018, 14, 221-227. [CrossRef] 
3. Dayi, B.; Kyzy, A.D.; Abduloglu, Y.; Cikrikci, K.; Akdogan, H.A. Investigation of the ability of immobilized cells to different carriers in removal of selected dye and characterization of environmentally friendly laccase of Morchella esculenta. Dye. Pigment. 2018, 151, 15-21. [CrossRef]

4. Lellis, B.; Fávaro-Polonio, C.Z.; Pamphile, J.A.; Polonio, J.C. Effects of textile dyes on health and the environment and bioremediation potential of living organisms. Biotechnol. Res. Innov. 2019, 3, 275-290. [CrossRef]

5. Papić, S.; Koprivanac, N.; Lončarić Božić, A.; Meteš, A. Removal of some reactive dyes from synthetic wastewater by combined Al(III) coagulation/carbon adsorption process. Dye. Pigment. 2004, 62, 291-298. [CrossRef]

6. Lin, L.; Zhu, W.; Zhang, C.; Hossain, M.Y.; Oli, Z.B.S.; Pervez, M.N.; Sarker, S.; Hoque, M.I.U.; Cai, Y.; Naddeo, V. Combination of wet fixation and drying treatments to improve dye fixation onto spray-dyed cotton fabric. Sci. Rep. 2021, 11, 15403. [CrossRef]

7. Haque, A.N.M.A.; Hannan, M.; Rana, M.M.J.F. Compatibility analysis of reactive dyes by exhaustion-fixation and adsorption isotherm on knitted cotton fabric. Fash. Tex. 2015, 2, 1-12. [CrossRef]

8. Mirzaei, N.; Ghaffari, H.R.; Sharafi, K.; Velayati, A.; Hoseindoost, G.; Rezaei, S.; Mahvi, A.H.; Azari, A.; Dindarloo, K. Modified natural zeolite using ammonium quaternary based material for Acid red 18 removal from aqueous solution. J. Environ. Chem. Eng. 2017, 5, 3151-3160. [CrossRef]

9. Jabar, J.M.; Odusote, Y.A. Removal of cibacron blue 3G-A (CB) dye from aqueous solution using chemo-physically activated biochar from oil palm empty fruit bunch fiber. Arab. J. Chem. 2020, 13, 5417-5429. [CrossRef]

10. Pajootan, E.; Arami, M.; Mahmoodi, N.M. Binary system dye removal by electrocoagulation from synthetic and real colored wastewaters. J. Taiwan Inst. Chem. Eng. 2012, 43, 282-290. [CrossRef]

11. Aravind, P.; Selvaraj, H.; Ferro, S.; Sundaram, M. An integrated (electro- and bio-oxidation) approach for remediation of industrial wastewater containing azo-dyes: Understanding the degradation mechanism and toxicity assessment. J. Hazard. Mater. 2016, 318, 203-215. [CrossRef] [PubMed]

12. Liu, C.-C.; Hsieh, Y.-H.; Lai, P.-F.; Li, C.-H.; Kao, C.-L. Photodegradation treatment of azo dye wastewater by $\mathrm{UV} / \mathrm{TiO} \mathrm{O}_{2}$ process. Dye. Pigment. 2006, 68, 191-195. [CrossRef]

13. Katheresan, V.; Kansedo, J.; Lau, S.Y. Efficiency of various recent wastewater dye removal methods: A review. J. Environ. Chem. Eng. 2018, 6, 4676-4697. [CrossRef]

14. Alvarez, L.H.; Arvizu, I.C.; Garcia-Reyes, R.B.; Martinez, C.M.; Olivo-Alanis, D.; Del Angel, Y.A. Quinone-functionalized activated carbon improves the reduction of congo red coupled to the removal of p-cresol in a UASB reactor. J. Hazard. Mater. 2017, 338, 233-240. [CrossRef]

15. Bayramoglu, G.; Salih, B.; Akbulut, A.; Arica, M.Y. Biodegradation of Cibacron Blue 3GA by insolubilized laccase and identification of enzymatic byproduct using MALDI-ToF-MS: Toxicity assessment studies by Daphnia magna and Chlorella vulgaris. Ecotoxicol. Environ. Saf. 2019, 170, 453-460. [CrossRef]

16. Rodríguez, S. Dye removal by immobilised fungi. Biotechnol. Adv. 2009, 27, 227-235. [CrossRef] [PubMed]

17. Cabana, H.; Ahamed, A.; Leduc, R. Conjugation of laccase from the white rot fungus Trametes versicolor to chitosan and its utilization for the elimination of triclosan. Bioresour. Technol. 2011, 102, 1656-1662. [CrossRef] [PubMed]

18. Arregui, L.; Ayala, M.; Gómez-Gil, X.; Gutiérrez-Soto, G.; Hernández-Luna, C.E.; de los Santos, M.H.; Levin, L.; Rojo-Domínguez, A.; Romero-Martínez, D.; Saparrat, M.C.N.; et al. Laccases: Structure, function, and potential application in water bioremediation. Microb. Cell Fact. 2019, 18, 200. [CrossRef]

19. Blánquez, A.; Rodríguez, J.; Brissos, V.; Mendes, S.; Martins, L.O.; Ball, A.S.; Arias, M.E.; Hernández, M. Decolorization and detoxification of textile dyes using a versatile Streptomyces laccase-natural mediator system. Saudi J. Biol. Sci. 2019, 26, 913-920. [CrossRef]

20. Mtibaa, R.; Barriuso, J.; de Eugenio, L.; Aranda, E.; Belbahri, L.; Nasri, M.; Martinez, M.J.; Mechichi, T. Purification and characterization of a fungal laccase from the ascomycete Thielavia sp. and its role in the decolorization of a recalcitrant dye. Int. J. Biol. Macromol. 2018, 120 Pt B, 1744-1751. [CrossRef]

21. Cruz-Ramírez, M.G.; Rivera-Ríos, J.M.; Téllez-Jurado, A.; Maqueda-Gálvez, A.P.; Mercado-Flores, Y.; Arana-Cuenca, A. Screening for thermotolerant ligninolytic fungi with laccase, lipase, and protease activity isolated in Mexico. J. Environ. Manag. 2012, 95, S256-S259. [CrossRef] [PubMed]

22. Maldonado-Bustamante, S.R.; Mondaca-Fernández, I.; Caro-Reyes, R.B.; Gámez-Gutierrez, L.A.; Santos-Villalobos, S.; Meza-Montenegro, M.M.; Balderas-Cortés, J.J. Selección de cepas productoras de enzimas ligninolíticas nativas del Valle del Yaqui. Nova Sci. 2017, 9, 24-36. [CrossRef]

23. Singh, D.; Gupta, N. Microbial Laccase: A robust enzyme and its industrial applications. Biologia 2020, 75, 1183-1193. [CrossRef]

24. Ma, H.F.; Meng, G.; Cui, B.K.; Si, J.; Dai, Y.C. Chitosan crosslinked with genipin as supporting matrix for biodegradation of synthetic dyes: Laccase immobilization and characterization. Chem. Eng. Res. Des. 2018, 132, 664-676. [CrossRef]

25. Daâssi, D.; Rodríguez-Couto, S.; Nasri, M.; Mechichi, T. Biodegradation of textile dyes by immobilized laccase from Coriolopsis gallica into Ca-alginate beads. Int. Biodeterior. Biodegrad. 2014, 90, 71-78. [CrossRef]

26. Campia, P.; Ponzini, E.; Rossi, B.; Farris, S.; Silvetti, T.; Merlini, L.; Brasca, M.; Grandori, R.; Galante, Y.M. Aerogels of enzymatically oxidized galactomannans from leguminous plants: Versatile delivery systems of antimicrobial peptides and enzymes. Carbohydr. Polym. 2017, 158, 102-111. [CrossRef]

27. Cerqueira, M.A.; Bourbon, A.I.; Pinheiro, A.C.; Martins, J.T.; Souza, B.W.S.; Teixeira, J.A.; Vicente, A.A. Galactomannans use in the development of edible films/coatings for food applications. Trends Food Sci. Technol. 2011, 22, 662-671. [CrossRef] 
28. Zheng, F.; Cui, B.; Wu, X.; Meng, G.; Liu, H.; Si, J. Immobilization of laccase onto chitosan beads to enhance its capability to degrade synthetic dyes. Int. Biodeterior. Biodegrad. 2016, 110, 69-78. [CrossRef]

29. Yavaşer, R.; Karagözler, A.A. Laccase immobilized polyacrylamide-alginate cryogel: A candidate for treatment of effluents. Process Biochem. 2021, 101, 137-146. [CrossRef]

30. Kuster, E.; Williams, S.T. Selection of media for isolation of Streptomycetes. Nature 1964, 202, 928-929. [CrossRef]

31. Gardes, M.; Bruns, T.D. ITS primers with enhanced specificity for basidiomycetes-application to the identification of mycorrhizae and rusts. Mol. Ecol. 1993, 2, 113-118. [CrossRef]

32. Altschul, S.F.; Gish, W.; Miller, W.; Myers, E.W.; Lipman, D.J. Basic local alignment search tool. J. Mol. Biol. 1990, 215 , 403-410. [CrossRef]

33. Tamura, K.; Nei, M.; Kumar, S. Prospects for inferring very large phylogenies by using the neighbor-joining method. Proc. Natl. Acad. Sci. USA 2004, 101, 11030-11035. [CrossRef] [PubMed]

34. Miller, G.L. Use of Dinitrosalicylic acid reagent for determination of reducing sugar. Anal. Chem. 1959, 31, 426-428. [CrossRef]

35. Keesey, J. Biochemica Information: A Revised Biochemical Reference Source; Boehringer Mannheim Biochemicals: Indianapolis, IN, USA, 1987.

36. Shekher, R.; Sehgal, S.; Kamthania, M.; Kumar, A. Laccase: Microbial sources, production, purification, and potential biotechnological applications. Enzym. Res. 2011, 2011, 217861.

37. Viswanath, B.; Rajesh, B.; Janardhan, A.; Kumar, A.P.; Narasimha, G. Fungal laccases and their applications in bioremediation. Enzym. Res. 2014, 2014, 163242. [CrossRef] [PubMed]

38. Myasoedova, N.M.; Renfeld, Z.V.; Podieiablonskaia, E.V.; Samoilova, A.S.; Chernykh, A.M.; Classen, T.; Pietruszka, J.; Kolomytseva, M.P.; Golovleva, L.A. Novel laccase_producing ascomycetes. Microbiology 2017, 86, 503-511. [CrossRef]

39. Bagewadi, Z.K.; Mulla, S.I.; Ninnekar, H.Z. Purification and immobilization of laccase from Trichoderma harzianum strain HZN10 and its application in dye decolorization. J. Genet. Eng. Biotechnol. 2017, 15, 139-150. [CrossRef]

40. Lassouane, F.; Ait-Amar, H.; Amrani, S.; Rodriguez-Couto, S. A promising laccase immobilization approach for Bisphenol A removal from aqueous solutions. Bioresour. Technol. 2019, 271, 360-367. [CrossRef]

41. Othman, A.; Elshafei, A.; Elsayed, M.; Hassan, M. Decolorization of Cibacron Blue 3G-A Dye by Agaricus bisporus CU13 Laccase-Mediator System: A Statistical Study for Optimization via Response Surface Methodology. Annu. Res. Rev. Biol. 2018, 25, 1-13. [CrossRef]

42. Reda, F.M.; Hassan, N.S.; El-Moghazy, A.-N. Decolorization of synthetic dyes by free and immobilized laccases from newly isolated strain Brevibacterium halotolerans N11 (KY883983). Biocatal. Agric. Biotechnol. 2018, 15, 138-145. [CrossRef]

43. Sharifi-Bonab, M.; Rad, F.; Mehrabad, J.T. Preparation of laccase-graphene oxide nanosheet/alginate composite: Application for the removal of cetirizine from aqueous solution. J. Environ. Chem. Eng. 2016, 4, 3013-3020. [CrossRef]

44. Kashefi, S.; Borghei, S.M.; Mahmoodi, N.M. Covalently immobilized laccase onto graphene oxide nanosheets: Preparation, characterization, and biodegradation of azo dyes in colored wastewater. J. Mol. Liq. 2019, 276, 153-162. [CrossRef]

45. Bilal, M.; Jing, Z.; Zhao, Y.; Iqbal, H.M.N. Immobilization of fungal laccase on glutaraldehyde cross-linked chitosan beads and its bio-catalytic potential to degrade bisphenol A. Biocatal. Agric. Biotechnol. 2019, 19, 101174. [CrossRef] 